\title{
PRICE SENSITIVITY ANALYSIS ON PURCHASING DECISION PROCESS OF DURIAN IN JEPARA REGENCY AND SEMARANG CITY CENTRAL JAVA
}

\author{
Khofiatun Nida ${ }^{\text {I) }}{\text { Titik } \text { Ekowati }^{2)} \text { Siswanto Imam Santoso }}^{2)}$ \\ ${ }^{1)}$ Program of Agribusiness, Faculty of Animal Husbandry and Agriculture Diponegoro University, Campus drh. R. \\ Soejono Koesoemowardojo, Tembalang, Semarang City. Email: khofianida96@gmail.com \\ ${ }^{2)}$ Faculty of Animal Husbandry and Agriculture Universitas Diponegoro, Kampus drh. R. Soejono Koesoemowardojo, \\ Tembalang, Semarang City
}

\begin{abstract}
Uncertainty of harvested area and the amount of durian production each year makes the price of the durian tend to fluctuate. Price changes can trigger price sensitivity at the consumer level. This study aimed to analyze the level of durian price sensitivity in Jepara Regency and Semarang City and analyze the factors that make the process of buying durian in Jepara Regency and Semarang City. The analysis used in this research was descriptive analysis and logistic regression analysis. The price suggests that the price of Jepara Regency and Semarang City is IDR $45,000.00-50,000.00$. Overall price levels received durian consumers in the Semarang City was higher than Jepara Regency. Based on the results of logistic regression analysis, it is known that simultaneously the price factor, income, occupation, age, taste, shape, size, aroma, color. and size.
\end{abstract}

Keyword: Durian, Price, Price sensitivity, Purchasing decision.

\section{INTRODUCTION}

Durian (Durio zibethinus Murr.) Is one type of fruit that is consumed by many people in Indonesia with a wide range of varieties. Durian plants are included in the Bombaceae family of kapok-kapukan trees. This plant is in the genus Durio, Nesia, Lahia, Boschia, Coelostagia. Variety of durian in Indonesia, such as sukun durian, petruk durian, sitokong durian, simas durian, sunan durian and others (Wijaya, 2007).

Durian is included in annual crops, so it has a harvest season once a year. Jepara regency and Semarang city are durian producing areas in Central Java. This area has different harvest and production area, where the average of harvested area and production of Jepara Regency is higher than Semarang City. Differences in harvested area and the number of durian production each year in both Jepara and Semarang affect the price of durian due to the related durian quantity in the market.
When the quantity of production falls, the price tends to rise. Conversely, when the amount of production rises then prices tend to fall. Price is one important component in marketing durian. The price will be related to the purchasing power of the consumer and affect the purchasing decision process of a product. Consumers will usually do a best price search before making a purchase. Pricing is influenced by the type of durian, size and season. Durian that has a taste better than other durian will have higher prices and vice versa (Mukminatin and Harisudin, 2012).

The price offered by the producer will produce different effects for each consumer. Differences in influence occur because of the sensitivity of prices perceived by each consumer (Rahman, 2005). The sensitivity of consumer prices is determined by how much information consumers get and the quality of the product. Consumers tend to lower the level of sensitivity if they have more product information, on the contrary, if consumers 
are less aware of product information, it will tend to increase the sensitivity. The incidence of price sensitivity will affect the purchase decision durian. Other factors that can influence the purchase decision durian of age, income, job, education level of the consumer, and physical attribute of durian fruit such as flavor, aroma, color, shape and size.

Based on the background of existing problems, this study is aimed to: 1) Analyze the sensitivity level of durian consumer prices in Jepara regency and in Semarang city, 2) to analyze the factors influencing the buying decision of durian in Jepara regency and in Semarang city.

\section{RESEARCH METHODS}

The study was conducted from October to November 2017 in Jepara Regency and Semarang City, Central Java.

The research method used is survey method, a research which take several samples from one population by using questionnaire as a tool to collect data (Jogiyanto, 2010).

Determination of the location of the sample is done intentionally (purposive). Criteria used is the area of durian centers in Jepara and Semarang.

Sampling method is done by non probability sampling method, that is convenience sampling of 100 responden.

Data collection is done through interview with the help of questionnaire to find primary data and secondary data to be used in research.

Data analysis method. Data analysis used in this research is descriptive analysis and logistic regression analysis. This study uses price research that consumers expect where price limits and price range can be accepted by consumers.

Logistic regression analysis is used to analyze whether there is influence of price sensitivity to durian purchasing decision in Jepara regency and Semarang city and to analyze other factors related to durian purchasing decision in Jepara regency and Semarang city. The modeling procedure is applied by modeling the response variables $(\mathrm{Y})$ that are categorized based on one or more predictor variables (X), whether they are category or continuous (Hosmer and Lemeshow, 2000). Logistic regression model in this research is as follows:

$Y i j=f(X i j)$

Yij $=0$, meaning the consumer does not buy the product

Yij $=1$, means consumers buy the product Where,

Yij = Opportunity purchase decision durian, buy or not

$\mathrm{X} 1=$ Price $(\mathrm{Rp})$

$\mathrm{X} 2=$ Revenue $(\mathrm{Rp})$

$\mathrm{X} 3=$ Age $($ Score $)$

$\mathrm{X} 4=$ Work $($ Score $)$

$\mathrm{X} 5$ = Flavor $($ Score $)$

X6 $=$ Shape (Score)

$\mathrm{X} 7=$ Size (Score)

$\mathrm{X} 8=$ Color $($ Score $)$

$\mathrm{X} 9=$ Aroma $($ Score $)$

\section{RESULTS AND DISCUSSION}

Based on the results of primary data collection by using questionnaires, the general overview results can be seen in terms of age, gender, income education and occupation levels are presented in Table 1.

Based on Table 1 it is known that most durian consumers are age group 21-30 years old. Age affects the tastes of consumers to consume products. Kotler and Keller (2007) argue that one's appetite for the product is age-related and shaped by the life cycle and the number of families, and the household's gender. The results showed more female consumers than male consumers. This can be attributed to the fact that more women do their family's shopping activities than men. putri et al. (2007) states that women generally play a role in making purchasing decisions and spending activities in the fulfillment of needs and consumption. 
Table 1. Respondent Characteristics

\begin{tabular}{|c|c|c|c|}
\hline \multirow{2}{*}{ AGE } & CATEGORY & \multirow[t]{2}{*}{ AMOUNT } & \multirow[t]{2}{*}{ PERCENTAGE } \\
\hline & $\leq 20$ & & \\
\hline & $21-30$ & & \\
\hline & $31-40$ & & \\
\hline & $41-50$ & & \\
\hline & $>50$ & & \\
\hline \multirow[t]{2}{*}{ GENDER } & Male & & \\
\hline & Women & & \\
\hline \multirow{5}{*}{$\begin{array}{l}\text { EDUCATION } \\
\text { LEVEL }\end{array}$} & Junior School & & \\
\hline & Junior High School & & \\
\hline & Senior High School & & \\
\hline & Diploma & & \\
\hline & Bachelor & & \\
\hline \multirow[t]{5}{*}{ JOB } & Housewife's & & \\
\hline & Wraswasta & & \\
\hline & Civil servants & & \\
\hline & College student & & \\
\hline & Employee & & \\
\hline \multirow[t]{3}{*}{ REVENUE } & $<\operatorname{Rp} 2,000,000$ & & \\
\hline & $\operatorname{Rp} 2,000,000-\operatorname{Rp} 7,000,000$ & & \\
\hline & $\operatorname{Rp} 7,000,000-\operatorname{Rp} 11,000,000$ & & \\
\hline
\end{tabular}

Source: Primary data processed, 2017

The last education level of most respondents is high school graduates by $59 \%$. Sumarwan (2004) said consumers who have better education will be very responsive to the information attached to the durian. Different education will cause consumers taste to be different. Respondents with entrepreneurial jobs were the respondents who bought the most durian with a percentage of $41 \%$. Based on the income level, the respondent who bought the most durian fruit is the respondent with income $\mathrm{Rp} \mathrm{2,000,000} \mathrm{-} \mathrm{Rp} \mathrm{7,000,000} \mathrm{for}$ $39 \%$. Revenue can affect consumer purchasing power and affect the product to be consumed. Simamora (2004) states that income greatly affects a person products choice.

Price Sensitivity Analysis. Price sensitivity analysis is shown in graphic form showing five price points based on consumer perception. According to Lewis and Shoemaker (1997) the five price points are:

\section{Indifferent Pricing Point (IPP)}

IPP is the point of intersection between the cumulative distribution of the cheap-expensive price, which is generated when the respondent stating the low price is equal to the respondents who stated the price is expensive.

\section{Optimum Pricing Point (OPP)}

OPP is the point of intersection between a very cheap price and a very expensive price. This rate shows the optimum price for the product because the consumer considers the price to be very expensive or very cheap.

\section{Range of Acceptable Price (RAP)}

RAP is a range of acceptable product prices by consumers derived from the intersection of the cumulative distribution of cheap and very cheap prices (Marginal Cheap Price) with the intersection of the cumulative distribution of expensive and very expensive (Marginal Expensive Price). 


\section{Marginal Cheap Price Point (MCP)}

The intersection of cheap and very cheap. At this price level consumers begin to doubt the quality of the product.

\section{Marginal Expensive Price Point (MEP)}

The intersection of expensive and very expensive. This price level is considered very expensive and consumers will start not to consume products.

fig 1 . Shows the lowest price level (MCP) in Jepara Regency is Rp 20.000,00. This price is the lowest price for durian fruit. Consumers evaluate at this price level durian has a minimum quality standards. Durian with price below MCP assessed to have a bad quality, in terms of taste, fruit size and thickness of durian meat. Meanwhile, the highest price level (MEP) in Jepara regency is Rp 70.000,00. This price is the highest bargain price of durian, so consumers tend to reduce purchases when the price of durian exceeds MEP. Consumers who do not really like durian fruit will change to buy another fruit or cancels buyingif the price level exceeds MEP. The results showed the price range received by consumers Rp 20.000,00 $\mathrm{Rp} 70.000,00$. Prices in this range are rated by consumers as the most appropriate price in durian purchases. Durian quality offered at this price range is rated by consumers as good and in accordance with the price paid.

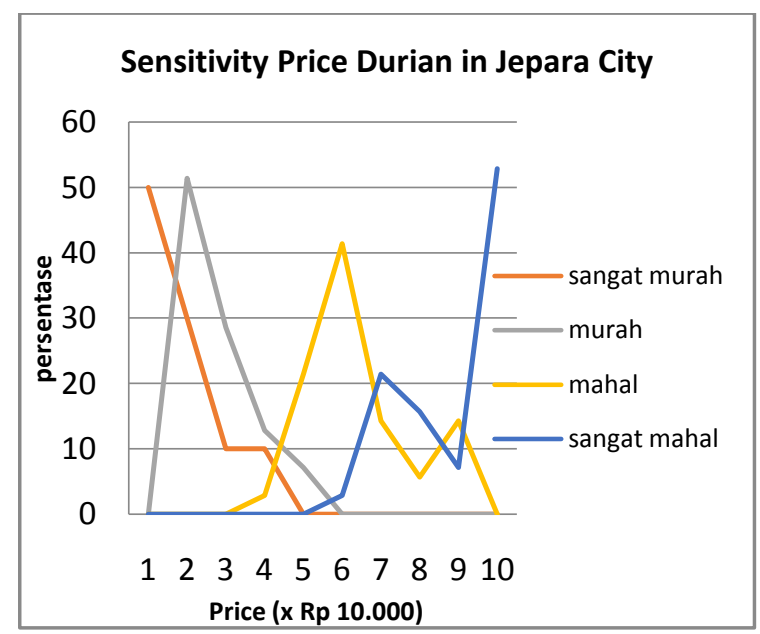

fig 1. Sensitivity of Durian Price in Jepara District

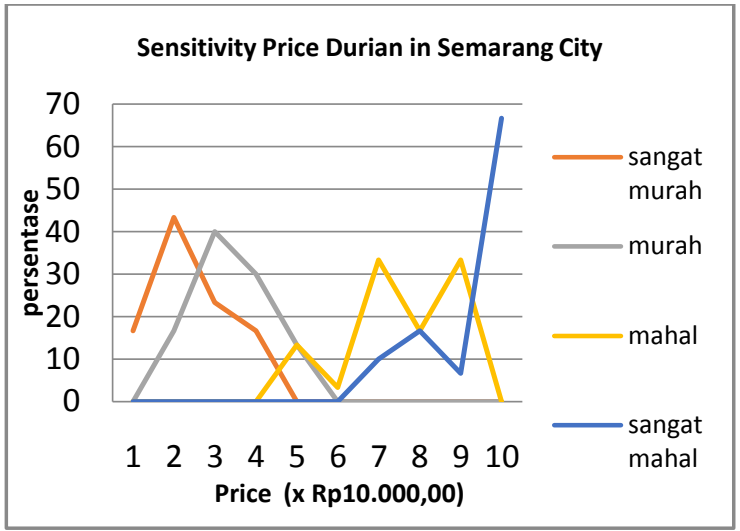

Fig 2. Sensitivity of Durian Price in Semarang City

Price sensitivity in Semarang City is similar to price sensitivity in Jepara regency. The difference lies in the value of the price level where the city of Semarang is higher than the Regency of Jepara. MCP Kota Semarang Rp 25.000,00. MEP is $\mathrm{Rp} 80.000,00$ and the price range is Rp 25.000,00 - Rp 80.000,00. More details are presented in fig 2.

Based on graphs 1 and 2, it can be concluded that respondents' assessment of the existing price level in Jepara and Semarang regencies as presented in Table 2.

Based on all the price level received by consumers in Semarang city is higher than in Jepara regency. This is due to the condition of Semarang City which has higher economic value than Jepara regency. Cannon et al. (2008) states that economic value is an important factor in many purchasing decisions. The income level obtained can be compared from the regional UMR, where UMR in Semarang city is higher than Jepara regency, so the income of respondents in Semarang city can be indicated higher than Jepara. This affects consumer consumption patterns in these two areas. Buchari (2004) states that consumption patterns will have different variations in the purchase decision of a product, one of the factors that influence it is income.

Factors Affecting Purchase Decision Durian. Based on the results of the data using SPSS program, it can be seen that the 
data valid and reliable in view of the Corrected Item-Total Correlation $>\mathrm{r}$ table and the value of cronbach's alpha> 0.6. Wardana (2011) states that the questionnaire items are valid if Corrected Item-Total Correlation> $r$ table with sig level. 5\%. Njoto (2016) states that reliability test assessments are said to be reliable can be seen from the value of cronbach's alpha. The criterion used is if the coefficient of croncach's alpha is more than the specified critical value $(0.6)$ then the question item in the questionnaire is said to be reliable.

The simultaneous test results show that sig. model 0.000 , because the value is smaller than $5 \%$ at $5 \%$ level of significance, so it is concluded that the independent variables used together affect the purchase decision durian. Seen from Chi-square value, Chi-square value $>\mathrm{X} 2$ table at df 9 with significance 0,05 so it can be concluded that there is significant influence simultaneously independent variable to dependent variable. This is in accordance with the opinion of Gujarati (2004) which states that if the Chi-square value model> Chi-Square table then independent variables significantly influence simultaneously to the dependent variable.

Partial test results show that variables that have significant partial effect are price and size variables with coefficient values respectively $0.307(\mathrm{sig}=0,020)$ and $0,512(\operatorname{sig}=0,050)$. The significance value less than 0.05 means significant effect. This is in accordance with the opinion of Ekananda (2014) which states that the variable is significant if the value of $p$ value (sig) <0.05. Meanwhile, the variables of taste, shape, aroma, color, age, work and income did not significantly influence due to sig value $>0,05$.

Variables of taste, shape, aroma have no significant effect because there are groups of respondents who buy durian fruit just to feel the durian without considering the taste and quality aspects. Usually the group of respondents is a group of respondents with middle to lower income. These respondents only pay attention to aspects of price and size when buying durian. Meanwhile, age factor, occupation and income are not significant effect because the durian cosical is not limited of a certain age. Durian is acceptable to all age groups. Job and income factors have no significant effect because durian consumers are more inclined to their individual tastes. Consumers who are very fond of durian fruit will still buy durian fruit even though the price is expensive and does not pay attention to the income earned despite a reduction in the frequency of purchase compared to the durian is in the harvest season and the price offered is relatively cheaper.

Table 2. Results Sensitivity Analysis of the Price of Jepara Regency and Semarang City.

\begin{tabular}{|c|c|c|c|c|c|}
\hline $\begin{array}{l}\text { Durian } \\
\text { sensitivity } \\
\text { analysis }\end{array}$ & $\begin{array}{l}\text { Marginal } \\
\text { Cheap } \\
\text { Price point } \\
\text { (MCP) }\end{array}$ & $\begin{array}{l}\text { Indifferent } \\
\text { Pricing Point } \\
\text { (IPP) }\end{array}$ & $\begin{array}{c}\text { Range of } \\
\text { Acceptable } \\
\text { Price (RAP) }\end{array}$ & $\begin{array}{l}\text { Optimum } \\
\text { Pricing Point } \\
\quad(\mathrm{OPP})\end{array}$ & $\begin{array}{c}\text { Marginal } \\
\text { Expensive Price } \\
\text { point (MEP) }\end{array}$ \\
\hline Jepara & Rp 20.000,- & Rp 45.000,- & $\begin{array}{c}\text { Rp 20.000,- } \\
-\operatorname{Rp} 70.000,-\end{array}$ & Rp 50.000,- & Rp 70.000,- \\
\hline Semarang & Rp 25.000,- & Rp 50.000,- & $\begin{array}{c}\text { Rp 25.000,-- } \\
\text { Rp 80.000,- }\end{array}$ & Rp 60.000,- & Rp 80.000,- \\
\hline
\end{tabular}

Source: Primary Data Processed, 2017. 


\section{CONCLUSION AND \\ RECOMMENDATION}

\section{Conclusion}

(1) The sensitivity of durian price in Jepara Regency and Semarang City shows different result. Consumers in the city of Semarang more able to receive a higher price level compared with durian consumers in Jepara.

(2) Factors that influence the purchase decision durian price and size. Simultaneously all factors such as price, income, occupation, age, taste, shape, size, aroma and color have a significant effect on durian purchasing decision.

\section{Suggestion}

(1) If durian traders plan to raise the price of durian fruit, the price should not exceed the optimum price of the product (MEP) to prevent consumers switching to other fruit or reduce the quantity of durian purchases.

(2) In the event of a price increase, the trader should pay more attention to the characteristics of the consumer, so that when the price of the product rises or there are other policies related to marketing and sales can be adjusted to individual preferences.

\section{REFERENCE}

Buchari, A. 2004. Manajemen Pemasaran dan Pemasaran Jasa. Alfabeta, Bandung.

Cannon, J.P., W.D. Perreault, dan Jr.E. J. McCarthy. 2008. Pemasaran Dasar Edisi 16. Karya Salemba Empat, Jakarta.

Ekananda, M. 2014. Analisis Ekonometrika Data Penel. Edisi Pertama. Mitra Wacana Media, Jakarta.

Gujarati, D. N. 2004. Ekonometri Dasar. Erlangga, Jakarta.

Hosmer, D.W. dan S. Lemeshow. 2000. Applied Logistic Regression. John Willey \& Sons Inc, New York.

Jogiyanto, H. M. Metodologi Penelitian Bisnis. BPFE, Yogyakarta.

Kotler. P. dan Keller K. L. 2007. Manajemen Pemasaran. PT Indeks, Jakarta.

Lewis, R. C. dan S. Shoemaker. 1997. "Price Sensitivity Measurement : A tool for the Hospitality Industry." Cornell Hotel and Restaurant Administration Quarterly. 38 (2) : 44-54.

Mukminatin, S. N. dan M. Harisudin. 2012. Startegi pemasarn durian sanggaran (Duriozibethinus M.) di Kecamatan Matesih Kabupaten Karanganyar dengan metode competitive profile matrix (CPM). J. sosial ekonomi pertanian. 1 (1) : 15 - 32.

Njoto, T. K. 2016. Pengaruh desain kemasan, cita rasa, dan variasi produk terhadap keputusan pembelian konsumen bumi anugerah. J. Manajemen dan Start-Up Bisnis. 4 (1) : 455 - 463.

Putri, D., Yusmini, dan Eliza. 2017. Analisis bauran pemasaran terhadap keputusan pembelian konsumen raudhah chicken di Jalan Durian Pekan Baru. J. Faperta. 4 (2) : 1 - 15.

Rahman, H. W. 2005. Analisis Faktor-Faktor yang Mempengaruhi Tinggi Rendahnya Sensitivitas Harga pada PT Campina Ice Cream Industri Bandung. Fakultas Ekonomi. IPB (Skripsi).

Simamora, B. 2004. Riset Pemasaran. Gramedia Utama, Jakarta. 
Sumarwan, U. 2004. Perilaku Konsumen : Teori dan Penerapannya dalam Pemasaran. Ghalia Indonesia, Bogor.

Wardana, D. S. 2011. Pengaruh kepribadian konsumen pada pilihan merek sebgai konsep diri pada kategori produk. J. Aset. 1 (13) : $21-35$.

Wijaya, A. 2007. Bertanam Durian. Ganeca, Jakarta. 